\title{
Evaluation of The Timing of The Use of Hyperbaric Oxygen Therapy and Prognostic Factors in Sudden Hearing Loss
}

\section{Ani Issitme Kayıplarında Hiperbarik Oksijen Tedavisinin Uygulanma Zamanının ve Prognostik Faktörlerin Değerlendirilmesi}

Abdullah Arslan ${ }^{1}$

${ }^{1}$ Necmettin Erbakan University, Meram Faculty of Medicine, Department of Underwater and Hyperbaric Medicine, Konya, Turkey

Geliş Tarihi/Received: 13 May 2020 Kabul Tarihi/Accepted: 15 June 2020

Address correspondence to: Abdullah Arslan, Necmettin Erbakan University, Meram Faculty of Medicine, Department of Underwater and Hyperbaric Medicine, Konya, Turkey

e-mail: arsabdullah@gmail.com

ORCID

Abdullah Arslan

https://orcid.org/0000-0001-5575-326X

\begin{abstract}
Öz
Amaç: Ani işitme kayıplarında primer tedavi olarak önerilen hiperbarik oksijen (HBO) tedavisinin başlanma zamanının ve hastalara ait prognostik faktörlerin işitme kazancındaki etkileri araştırıldı.

Hastalar ve Yöntem: 1 Ocak 2016-31 Aralık 2016 tarihleri arasında tek merkezde tedavi edilmiş ani işitme kaybı nedeniyle HBO tedavisi uygulanan hastalar değerlendirildi. HBO tedavisinin başlanma zamanı, yaş, cinsiyet, sistemik steroid tedavisi, önceden var olan işitme kaybı ve kronik hastalıkların iyileşme evresi ve iyileşme düzeyleri sonuçlarına etkileri değerlendirildi.

Bulgular: Çalışmada 151 hastanın (97 erkek, 54 kadın) 164 kulağında tespit edilen ani işitme kaybı değerlendirildi. Ortalama $70,88 \pm 25,95 \mathrm{~dB}$ işitme kaybı tespit edildi. Hastalara 14,29 $\pm 7,0$ ( $\min 3-\max$ 30) seans HBO tedavisi uygulandı. Tedavi sonucunda $29,81 \pm 26,58 \mathrm{~dB}$ işitme kazancı sağlandı. HBO tedavisinin ilk 7 günde başlanmasının anlamlı olarak iyileşmeyi arttırdığı tespit edildi $(p<0,001)$. 50 yaş altı ve HBO tedavisi öncesinde sistemik steroid kullanmayan hastalarda iyileşme anlamlı düzeyde yüksek tespit edildi $(p<0,001, p<0,05)$. HBO tedavisinin ilk 7 günde uygulandığı ve HBO tedavisi öncesinde steroid tedavisi almayan hastalarda anlamlı olarak tam iyileşme (PTA $<26 \mathrm{~dB}$ ) daha yüksek tespit edildi $(x 2: 30,31 p<0,001, x 2: 7,86 p<0,04)$. Hastaların 8'inde $(\% 5,3)$ barotravma geliştiği, bu nedenle 2-5 gün HBO tedavisine ara verildikten sonra tedavinin devam ettiği tespit edilmiştir.

Sonuç: Illk 7 günde HBO tedavisi başlanan hastalarda, 50 yaş altı hastalarda ve HBO tedavisi öncesi steroid tedavisi almamış hastalarda daha iyi tedavi sonuçları elde edilmiştir. HBO tedavisine bağlı yan etkiler hastaların düşük bir kısmında tespit edilmiş ve tedavinin devamına engel olmadığı görülmüştür.
\end{abstract}

Anahtar Kelimeler: Hiperbarik oksijen tedavisi, ani işitme kaybı, prognostik faktörler

\section{Abstract}

Aim: The effects of hyperbaric oxygen (HBO) therapy, which is used as a primer treatment method for sudden hearing loss, is evaluated in regard to timing of the use and prognostic factors of the patients. Patients and Methods: Patients treated for sudden hearing loss in the same hyperbaric clinic between the dates 1 January 2016-31 December 2016 are evaluated. The effects of the timing of the start of HBO therapy, age, sex, use of systemic steroid treatment, prior hearing loss history and chronic diseases on recovery stage and level.

Results: In this study sudden hearing losses from 164 ears of 151 patients (97 men, 54 women) were evaluated. Median hearing loss values were $70,88 \pm 25,95 \mathrm{~dB}$. Number of $\mathrm{HBO}$ applied for patients was $14,29 \pm 7,0(\min 3-\max 30)$ sessions. $29,81 \pm 26,58 \mathrm{~dB}$ of hearing was recovered with the treatment. There was a statistically significant better improvement in hearing when HBO therapy was initiated in the first 7 days after the hearing loss $(p<0,001)$. Recovery in patients under the age of 50 and not taking steroids prior to HBO therapy was significantly higher $(p<0,001, p<0,05)$. Total recovery rates were significantly higher in patients to whom HBO therapy was initiated in the first 7 days and no steroid treatment was given before HBO therapy (PTA $<26 \mathrm{~dB})(x 2: 30,31, p<0,001, x 2: 7,86 \mathrm{p}<0,04) .8$ patients $(5,3 \%)$ had barotrauma and the treatment was continued after 2-5 days of break.

Conclusion: Better results were obtained in patients to whom HBO therapy was initiated in the first 7 days of the hearing loss, patients under the age of 50 and patients not taking steroids before HBO therapy. Side effects were observed in a low percentage of the patients and they weren't considered as an obstacle to continue the treatment.

Key words: Hyperbaric oxygen therapy, sudden hearing loss, prognostic factors.

Cite this article as: Arslan A. Evaluation of The Timing of The Use of Hyperbaric Oxygen Therapy and Prognostic Factors in Sudden Hearing Loss. Selcuk Med J 2020;36(3): 232-237
Disclosure: Author has not a financial interest in any of the products, devices, or drugs mentioned in this article. The research was not sponsored by an outside organization. Author has agreed to allow full access to the primary data and to allow the journal to review the data if requested. 


\section{INTRODUCTION}

$30 \mathrm{~dB}$ and higher levels of hearing loss in at least 3 consecutive frequencies, occurring in less than 3 days are considered as sudden hearing loss ( $\mathrm{SHL}$ ) (1). Many factors have been theorized to cause SHL but it is mostly thought to be caused by vascular, viral and immunologic factors (2). The frequency of this otologic emergency is not well documented due to the fact that spontaneous recovery is very common but the reported incidence is $5-27 / 100.000(3,4)$. Though is mostly unilateral, there can be rare cases of simultaneous bilateral loss. Symptoms like tinnitus, dizziness, loss of balance can also be observed (5).

The most commonly applied and recommended treatment modality for SHL is systemic steroids (6). Although it is an easy treatment to apply there are many side effects. It may cause side effects like dysregulation of blood glucose levels in diabetes mellitus (DM), hypertension, osteoporosis, avascular necrosis, cataract and glaucoma (7). Thus systemic steroid treatment may not be applied for some patients. Sometimes patients refuse to have the steroid treatment because of the side effects.

With the results of recent studies hyperbaric oxygen therapy (HBO) is considered a primary therapy method for SHL along with systemic steroid therapy (6). Blood partial oxygen pressure can be raised up to $1700-1800 \mathrm{mmHg}$ with hyperbaric oxygen therapy applied as breathing $100 \%$ oxygen in a closed system. By doing so some health benefits like more oxygen supply to tissues, decrease of edema and hypoxia, regulation on immune system are acquired (8). HBO raises oxygenation in the whole body as well as organs tike cochlea which are sensitive for ischemia.

HBO therapy, which is benefitted for the effects on vascular and immune system pathologies, is recommended to be added to the treatment modality along with systemic steroids in the first 2 weeks and continued as a salvation therapy up to 4 weeks (6). Some studies suggested early intervention is more beneficial for the efficacy of the treatment (9). In this study we investigated the effect of the time until the beginning $\mathrm{HBO}$ therapy after the occurrence of $\mathrm{SHL}$ and the effect of prognostic factors on treatment outcomes.

\section{PATIENTS AND METHOD}

This study is conducted after local ethics committee approval. SHL patients over the age of 18 whom received $\mathrm{HBO}$ therapy in Konya Training and Research Hospital Hyperbaric Oxygen Treatment
Clinic Hospital Hyperbaric Oxygen Treatment Clinic between the dates 1 January 2016-31 December 2016 were analyzed retrospectively. After evaluation patients that have conductive type hearing loss due to trauma are excluded from the study. Severity of the hearing loss and response to treatment is evaluated with audiometer test. Pure tone audiometric (PTA) median values were determined on $250,500,1000$, 2000, 4000 and $8000 \mathrm{~Hz}$ frequencies. Variables like demographic information of the patients, previous history of hearing loss of the effected ear or the other ear, chronic diseases, systemic or intratympanic steroid use before HBO therapy, number of days since the beginning of SHL, systemic or intratympanic steroid use along with $\mathrm{HBO}$ are evaluated. Pure tone audiometric (PTA) values before $\mathrm{HBO}$, hearing loss levels, hearing profit in decibels after the treatment and phases of recovery is investigated. Middle ear or sinus barotrauma cases due to HBO therapy is recorded.

The effect over treatment outcomes of starting HBO therapy in 0-7 days, 8-14 days and longer than 14 days are evaluated. The effect of systemic steroid use before HBO therapy, DM and HT anamnesis, history of previous hearing loss, sex, systemic steroid use along with steroids on treatment outcomes is studied.

Data is recorded in SPSS 18.0 programme. Coherence to normal distribution is analysed. Student T test is used for continuing numeric variables showing normal distribution; continuing numeric values with no normal distribution is evaluated with Mann Whitney $U$ test. Chi square test is used for the comparison of categoric data. Definitive statistics were documented as mean ( \pm standard deviation), median (min-max) for numeric variables, as percentage (\%) for qualitative variables. $\mathrm{P}<0,05$ is evaluated as significant for all analyses. Kruksal Wallis variance analysis and mann Whitney $U$ test with post hoc bonferroni correction is used for comparison of two or more groups.

\section{RESULTS}

164 ears from 151 patients received HBO therapy for SHL. $97(64,3 \%)$ of the patients were men and $54(35,7 \%)$ were women. Mean age was 47,18 $\pm 13,92$ (min 18-max 80$) .37$ (24,5\%) of the patients had HT and DM, $36(23,8 \%)$ had prior hearing loss history. $17(11,25 \%)$ of the patients weren't given systemic steroids either because of contradictions or because of patient's refusal. Mean hearing loss was 70,88 $\pm 25,95$. 43 patients $(26,2 \%)$ had mild, 61 patients $(37,2 \%)$ had 
Table 1. Demographic information of the patients

\begin{tabular}{lc}
\hline & $\mathbf{n}(\%)$ \\
\hline Age & $47,18 \pm 13,92(\min 18-\max 80)$ \\
Male & $97(\% 64,3)$ \\
HT, DM & $54(\% 35,7)$ \\
Prior hearing loss & $37(\% 24,5)$ \\
Steroid contraindicate & $36(\% 23,8)$ \\
\hline
\end{tabular}

moderate, 36 patients (22\%) had severe, 24 patients $(14,6 \%)$ had profound type hearing loss. (Table 1$)$

Patients received $\mathrm{HBO}$ therapy in a multiplace chamber under 2,4 pressure for 120 minutes per session and 5 days a week. Patients breath 100\% oxygen in 45 feet depth for $3 \times 25$ minutes, 5 minutes of air breaks were held between periods. Patients received $1 \mathrm{mg} / \mathrm{kg}$ methylprednisolone orally or i.v. and treatment was withdrawn gradually. Intratympanic steroids were applied with a dose of $0,5 \mathrm{~mL}$ dexamethasone ampules $(8 \mathrm{mg} / 2 \mathrm{~mL})$ every other day for 5 times. 53 patients $(32,3 \%)$ had the intratympanic steroid therapy and 104 patients $(63,4 \%)$ had the systemic steroid therapy along with HBO therapy. A mean $29,81 \pm 26,58 \mathrm{~dB}$ benefit in hearing was achieved with the treatment. Mean number of HBO sessions applied was $14,29 \pm 7,0.41$ of the patients $(25 \%)$ had total, 38 of the patients $(23,2 \%)$ had partial, 36 of

Table 2. Data of sudden hearing loss and the treatment

\begin{tabular}{ll}
\hline & $\mathbf{n}$ \\
\hline Baseline PTA (Mean dB) & $70,88 \pm 25,95$ \\
Level of hearing loss & \\
Mild $(25-40 \mathrm{~dB})$ & $43(\% 26,2)$ \\
Moderate $(41-60 \mathrm{~dB})$ & $61(37,2)$ \\
Severe $(61-80 \mathrm{~dB})$ & $36(\% 22,0)$ \\
Profound $(>80 \mathrm{~dB})$ & $24(\% 14,6)$ \\
Time until HBO application & $67(\% 40,9)$ \\
$0-7$ days & $25(\% 15,2)$ \\
$8-14$ days & $72(\% 43,9)$ \\
$>14$ days & $24(\% 15,89)$ \\
Number of HBO & $53(\% 35,09)$ \\
ITS before HBO & $53(\% 35,09)$ \\
ITS during HBO & $104(\% 68,87)$ \\
Systemic steroids before HBO & $29,81 \pm 26,58$ \\
Systemic steroids during HBO & \\
Recovery with HBO (Mean dB) & \\
Response to treatment with HBO & $41(\% 25)$ \\
Total (PTA<26 dB) & $38(23,2)$ \\
Partial (recovery $>29$ dB) & $36(\% 22)$ \\
Low (recovery 10-29 dB) & $49(\% 29,9)$ \\
No response (recovery < 10 dB) & $8(\% 5,3)$ \\
Barotrauma (Middle ear, Sinus) &
\end{tabular}

the patients $(22 \%)$ had low hearing benefit and there was no response to treatment in 49 patients $(29,9 \%)$. (Table 2)

8 patients $(5,3 \%)$ had middle ear or sınus barotraumas. HBO therapy was continued after 2 to 5 days of HBO therapy cessation and disappearance of symptoms. There wasn't a case where HBO sessions were stopped because of barotrauma. Treatment outcomes of starting HBO therapy in 0-7 days, 8-14 days and longer than 14 days after the hearing loss started were compared. Patients whom HBO therapy was initiated in 0-7 days had significantly better outcomes when compared to patients whom received the HBO therapy after the 14th day $(p<0,001)$. No significant difference in terms of hearing improvement was observed between 0-7 days and 8-14 days and between 8-14 days and longer than 14 days. (Table3)

Total recovery rate was significantly higher in patients whom HBO was initiated in the first 7 days when compared to 8-14 days and longer than 14 days of initiation of HBO therapy $\left(x^{2}: 30,31, p<0,001\right)$. (Table 4) Recovery rates of patients who received systemic steroid therapy and patients who didn't was compared. Patients who didn't receive systemic steroids before HBO therapy responses significantly better to treatment $(d B)(p<0,001)$. In this two groups it was also determined that total recovery was significantly higher in patients who didn't receive steroids before HBO $\left(x^{2}: 7,86, p: 0,004\right)$ (Table 4)

When the recovery rates were compared in between age groups; patients under the age of 50 showed significantly better improvement $(\mathrm{dB})$ than patients over $50(p<0,001)$ (Table 3$)$ No statistically significant difference in treatment outcomes was observed in the comparison of sex difference, prior hearing loss history, HT and DM comorbidity and appliance of systemic steroids along with $\mathrm{HBO}$.

Table 3. Comparison of recovery $(\mathrm{dB})$ in regard to timing of the start of $\mathrm{HBO}$, steroid use before $\mathrm{HBO}$ and age

\begin{tabular}{lll}
\hline & Mean rank & $\mathbf{p}$ \\
\hline Timing of the start of HBO & & \\
0-7 days* & 72,45 & $\mathrm{p}=0,001$ \\
8-14 days & 56,50 & \\
$>14$ days & 45,10 & \\
Steroids before HBO (+) & 41,00 & \\
Steroids before HBO $(-)^{*}$ & 73,70 & $\mathrm{p}<0,001$ \\
Age 18-50 * & 59,36 & $\mathrm{p}<0,001$ \\
Age $>50$ yaş & 36,49 & \\
\hline${ }^{*}$ Group creating the difference & &
\end{tabular}


Table 4. Comparison of the response to treatment with time period before $\mathrm{HBO}$ and use of steroids.

\begin{tabular}{|c|c|c|c|c|c|c|c|c|c|}
\hline & \multicolumn{3}{|c|}{$\mathbf{N}$} & \multirow[b]{2}{*}{$x^{2}$} & \multirow[b]{2}{*}{ p } & \multicolumn{2}{|c|}{$\mathbf{n}$} & \multirow[b]{2}{*}{$x^{2}$} & \multirow[b]{2}{*}{ p } \\
\hline & $0-7$ days & 8-14 days & $>14$ days & & & $\begin{array}{l}\text { Steroids } \\
\text { before HBO (-) }\end{array}$ & $\begin{array}{l}\text { Steroids } \\
\text { before HBO (+) }\end{array}$ & & \\
\hline Total recovery & $\begin{array}{c}29^{*} \\
(\% 70,7)\end{array}$ & $\begin{array}{c}8 \\
(\% 19,5)\end{array}$ & $\begin{array}{c}4 \\
(\% 9,8)\end{array}$ & 30,31 & $<0,001$ & $35^{*}(\% 85,4)$ & $6(\% 14,6)$ & 7,86 & 0,04 \\
\hline Partial recovery & $\begin{array}{c}16 \\
(\% 42,1)\end{array}$ & $\begin{array}{c}5 \\
(\% 13,2)\end{array}$ & $\begin{array}{c}17 \\
(\% 44,7)\end{array}$ & & & $24(\% 63,2)$ & $14(\% 36,8)$ & & \\
\hline Poor recovery & $10(\% 27,8)$ & $5(\% 13,9)$ & $21(\% 5$ & $8,3)$ & & $22(\% 61,1)$ & $14(\% 38,9)$ & & \\
\hline No recovery & $12(\% 24,5)$ & $7(\% 14,3)$ & $30(\% 6$ & $1,2)$ & & $30(\% 61,2)$ & $19(\% 38,8)$ & & \\
\hline
\end{tabular}

* group creating the difference

\section{DISCUSSION}

$\mathrm{SHL}$ is defined as the occurrence of $30 \mathrm{~dB}$ hearing loss in 3 consecutive frequencies within 3 days. Spontaneous recovery rates in the literature for SHL is between $32 \%$ and $65 \%(1,10)$. Spontaneous recovery rates are considered to be higher than anticipated. SHL which is an otological emergency may cause permanent hearing loss, tinnitus and may effect life quality (11). 164 ears from 151 patients are evaluated in this study. 43 of the patients had mild, 61 had moderate, 36 had severe, 24 had profound hearing loss. Patients received mean 14,29 $\pm 7,0$ (min 3- max 30) sessions of HBO therapy. After patients received HBO therapy a mean $29,81 \pm 26,58 \mathrm{~dB}$ of hearing benefit was achieved.

Many agents are used for SHL treatment but most common primary treatments are systemic steroids and HBO therapy (6). HBO therapy is used for SHL since 1970's because of its effect of raising partial oxygen pressure in the blood hence improving tissue oxygenation, reducing edema and hypoxia and regulating the immune response (12). Healing effects of hyperbaric oxygen therapy have been shown in different diseases $(13,14)$. Although these treatments are used some prognostic factors are reported to effect the response to treatment. One of these prognostic factors for both treatment modalities is the time until treatment initiation after SHL. In this study we studied the effects of time until treatment initiation after the occurrence of the pathology and other prognostic factors over treatment results.

In this study we determined that with initiation of HBO therapy within 7 days after SHL, treatment outcomes are significantly better when compared to patients with initiation after 14 days $(p<0,001)$. Yıldırım et al. (9) in a study of 59 patients reported better treatment outcomes when therapy was initiated within 0-7 days and 8-14 days when compared to initiation after the 14th day. Capuana et al. and Holy et al. reported significantly better outcomes when HBO therapy was initiated within 10 days, Nakasima et al. (15-17)reported better outcomes with initiation within 7 days.

Total recovery rates were significantly higher when HBO therapy was initiated within 7 days ( $x^{2}: 30,31$, $p<0,001)$. This study is in accordance with the current literature and it is suggested to consider HBO therapy as soon as possible when SHL is diagnosed.

56 of the patients in this study were referred to HBO therapy because no response was achieved with the prior systemic steroid treatment or intratympanic steroid injections. In these patients HBO therapy was considered as a salvage treatment and patients weren't referred for HBO in the early stages of SHL. When patient groups whom received systemic steroid treatment or intratympanic steroid injections compared to those who didn't, results suggested a significantly better outcome in groups with no prior steroid intervention $(p<0,001)$. Two causes may be responsible for these results. As mentioned above best response to HBO therapy was achieved when it's initiated within the first 7 days of SHL. In patients with no response to prior steroid treatment, HBO initiation time is delayed. The other reason can be the treatment resistance of these patients. New studies on the subject may reveal more clear results.

In this study 17 patients weren't given systemic steroids either because of comorbidities or patient rejection. 4 of these patients received intratympanic steroid injections. According to current treatment protocols most commonly accepted and used treatment modality is systemic steroids. Steroids must be used carefully because of side effects like dysregulation of blood sugar levels, HT, weight gain, avascular necrosis, osteoporosis, cataract, glaucoma. Treatment protocol is $1 \mathrm{mg} / \mathrm{kgs}$ of methylprednisolone 
which is withdrawn gradually in $10-15$ days. Aim is to minimize side effects. Waliee et al. (18) reported significantly more sepsis, venous thromboembolism and bone fractures with steroid use when compared to normal population. Most common side effect of HBO therapy is barotrauma. Barotrauma is tissue injury due to collapse or expansion of air in closed body spaces. Most common barotrauma type is middle ear barotrauma (19). In this study 8 patients $(5,3 \%)$ had middle ear or sinus barotrauma; inside chamber attended intervened in all cases to minimize the barotrauma injury. Patients continued their HBO therapy after 2-5 days of treatment break and barotrauma treatment. No other side effects were experienced in patients involved in the study.

Many studies in the literature reports better outcomes when systemic steroids are used along with HBO therapy $(6,15,20)$. In the studies, combined use of HBO therapy and steroids are related to better outcomes when compared to using each modalities alone. In this study there was no significant difference in patients whom received only HBO therapy when compared to patients whom took systemic steroids along with $\mathrm{HBO} .56$ patients $(37 \%)$ were referred to HBO therapy because no response was achieved with prior steroid treatment (systemic or intratympanic). We think this quantity of patients may have affected the comparison results. This study suggests no significant difference when steroids are used along with HBO therapy but we still recommend steroid treatment for patients receiving $\mathrm{HBO}$ therapy.

There are studies investigating SHL treatment results in relation to age groups. Aslan et al. and Topuz et al. $(21,22)$ reported significantly better outcomes with HBO therapy in patients under the age of 50 . Edizer et al. and Hosokowa et al. $(23,24)$ showed significantly worse treatment outcomes in patients over the age of 60 . In this study, when age groups $18-50$ and over 50 are compared; significantly better outcomes were recorded in the 18-50 age group $(p<0,001)$. In this study no significant difference in terms of treatment response was recorded with the comparison in the groups of simultaneous HBO and steroid treatment, prior hearing loss history and chronic diseases (HT, DM).

\section{CONCLUSION}

In this study effects of HBO therapy on SHL patients, prognostic factors that may alter treatment outcomes and side effects of HBO therapy was investigated. Results indicates that treatment outcomes are better when HBO therapy is initiated in the first 7 days, when patient age is below 50 and in patients whom didn't receive steroids before HBO therapy. Data about better outcomes in earlier $\mathrm{HBO}$ initiation and in patients under the age of 50 is in accordance with the literature. Patients whom received steroids before HBO therapy were referred for HBO because of inadequate response to steroid therapy. It is anticipated that the reason for less response to treatment is because therapy couldn't be initiated in the early phase and patients were resistant for treatment. HBO related side effects were observed in $5,3 \%$ of the patients and didn't affect treatment permanency.

Conflict of interest: Author declares that there is no conflict of interest between the authors of the article.

Financial conflict of interest: Author declares that he did not receive any financial support in this study.

Address correspondence to: Abdullah Arslan, Necmettin Erbakan University, Meram Faculty of Medicine, Department of Underwater and Hyperbaric Medicine, Konya, Turkey

e-mail: arsabdullah@gmail.com

\section{REFERENCES}

1. Stachler RJ, Chandrasekhar SS, Archer SM, et al. Clinical practice guideline: Sudden hearing loss. Otolaryngol Head Neck Surg 2012;146(3 Suppl):S1-S35.

2. Eisenman DJ, Arts HA. Effectiveness of treatment for sudden sensorineural hearing loss. Arch Otolaryngol Head Neck Surg 2000;126:1161-4.

3. Alexander TH, Harris JP. Incidence of sudden sensorineural hearing loss. Otol Neurotol 2013;34(9):1586-9.

4. Booth JB. Sudden and Fluctuant sensorineural hearing loss, In: Kerr AG, Editor. Scott Browns Otolaryngology. 6th ed. London: Butterworths-Heinemann 1997;3:1-82.

5. Kuhn M, Heman-Ackah SE, Shaikh JA, et al. Sudden sensorineural hearing loss: A review of diagnosis, treatment, and prognosis. Trends Amplif 2011;15(3):91-105.

6. Chandrasekhar SS, Tsai Do BS, Schwartz SR, et al. Clinical practice guideline: Sudden hearing loss (Update). Otolaryngol Head Neck Surg 2019;161(1_suppl):S1-45.

7. Grennan D, Wang S. Steroid side effects. JAMA 2019;322(3):282.

8. Gill AL, Bell CNA. Hyperbaric oxygen: Its uses, mechanisms of action and outcomes. QJM 2004;97:385-95.

9. Yıldırım E, Murat Özcan K, Palalı M, et al. Prognostic effect of hyperbaric oxygen therapy starting time for sudden sensorineural hearing loss. Eur Arch Otorhinolaryngol 2015;272(1):23-8.

10. Mattox DE, Simmons FB. Natural history of sudden sensorineural hearing loss. Ann Otol Rhinol Laryngol 1977;86:463-80.

11. Dallan I, Fortunato S, Casani AP, et al. Long-term follow up of sudden sensorineural hearing loss patients treated 
with intratympanic steroids: Audiological and quality of life evaluation. J Laryngol Otol 2014;128(8):669-73.

12. Appaix A, Demard F. Oxygénothérapie hyperbare et surdités brutales de perception [Hyperbaric oxygenotherapy and sudden perceptive deafness]. Rev Laryngol Otol Rhinol (Bord) 1970;91(11):951-72.

13. Arslan A, Dikici F, Purisa S, et al. Evaluation of short term effects of hyperbaric oxygen and enoxaparin treatments in avascular necrosis of femoral head. Selcuk Med J 2019;35(2): 77-84.

14. Ince B, Arslan A, Dadaci $M$, et al. The effect of different application timings of hyperbaric oxygen treatment on nerve regeneration in rats. Microsurgery 2016;36(7):586-92.

15. Capuano L, Cavaliere M, Parente G, et al. Hyperbaric oxygen for idiopathic sudden hearing loss: Is the routine application helpful? Acta Otolaryngol 2015;135(7):692-7.

16. Holy R, Navara M, Dosel P, et al. Hyperbaric oxygen therapy in idiopathic sudden sensorineural hearing loss (ISSNHL) in association with combined treatment. Undersea Hyperb Med 2011;38(2):137-42.

17. Nakashima T, Fukuta S, Yanagita N. Hyperbaric oxygen therapy for sudden deafness. Adv Otorhinolaryngol 1998;54:100-9.

18. Waljee AK, Rogers MA, Lin P, et al. Short term use of oral corticosteroids and related harms among adults in the United States: Population based cohort study. BMJ 2017;357:1415.
19. Mirasoğlu B, Cakkalkurt A, Çimşit M. Symptomatic middle ear and cranial sinus barotraumas as a complication of hyperbaric oxygen treatment. İstanbul Tıp Fakültesi Dergisi 2016;79.4:147-52.

20. Alimoglu Y, Inci E, Edizer DT, et al. Efficacy comparison of oral steroid, intratympanic steroid, hyperbaric oxygen and oral steroid + hyperbaric oxygen treatments in idiopathic sudden sensorineural hearing loss cases. Eur Arch OtoRhino-Laryngol 2011;268(12):1735-41.

21. Aslan I, Oysu C, Veyseller B, et al. Does the addition of hyperbaric oxygen therapy to the conventional treatment modalities influence the outcome of sudden deafness? Otolaryngol Head Neck Surg 2002;126(2):121-6.

22. Topuz E, Yigit O, Cinar U, et al. Should hyperbaric oxygen be added to treatment in idiopathic sudden sensorineural hearing loss? Eur Arch Otorhinolaryngol. 2004;261(7):393-6.

23. Edizer DT, Çelebi Ö, Hamit B, et al. Recovery of idiopathic sudden sensorineural hearing loss. J Int Adv Otol 2015;11(2):122-6.

24. Hosokawa S, Sugiyama K, Takahashi G, et al. Prognostic factors for idiopathic sudden sensorineural hearing loss treated with hyperbaric oxygen therapy and intravenous steroids. J Laryngol Otol 2017;131(1):77-82. 